\title{
Effects of thermal modification on physical and mechanical properties of Mozambican Brachystegia spiciformis and Julbernardia globiflora wood
}

\author{
Feliz Nhacila $^{1} \cdot$ Eunice Sitoe $^{1} \cdot$ Ernesto Uetimane $^{1} \cdot$ Alberto Manhica $^{2} \cdot$ Andrade Egas $^{1} \cdot$ Veikko Möttönen $^{3}$ (D)
}

Received: 13 September 2019 / Published online: 27 July 2020

(c) The Author(s) 2020

\begin{abstract}
Mozambique's large pool of tropical hardwoods is hampered by the prevalence of low-grade tree species along with a lack of cost-effective processing technologies to improve timber properties. Brachystegia spiciformis and Julbernadia globiflora are the most abundant tree species in terms of volume in the country, but with limited use due to their low timber quality. In this study, thermal modification at three different temperatures $\left(215^{\circ} \mathrm{C} ; 230{ }^{\circ} \mathrm{C} ; 245^{\circ} \mathrm{C}\right)$ was applied for $2 \mathrm{~h}$ to the timber of both species, followed by measurement of a set of physical and mechanical wood properties. The results show that the originally light-coloured sapwood of both tree species darkened gradually as the intensity of thermal modification increased. Additionally, from untreated samples to the highest thermal treatment level, timber of B. spiciformis incurred a maximum mass loss of $27 \%$, while oven-dry density was reduced from 0.65 to $0.56 \mathrm{~g} / \mathrm{cm}^{3}$ and equilibrium moisture content (EMC) changed from 7 to $3 \%$. Timber of J. globiflora had a mass loss of $23 \%$ after the highest treatment level, an oven-dry density reduction of 0.81 to $0.74 \mathrm{~g} / \mathrm{cm}^{3}$ and an EMC decrease from 8 to $3 \%$. The changes in mechanical properties from reference samples to the highest thermal treatment level were also significant. For B. spiciformis, MOE decreased by $10.2 \%$, MOR by $50.8 \%$, compression strength parallel to the grain by $29.2 \%$ and Brinell hardness by $23.5 \%$. Timber of $J$. globiflora followed the same trend with an MOE decrease by $6.9 \%$, an MOR decrease by $53.2 \%$ and a decrease in compression strength parallel to the grain by $21.9 \%$. All tested wood properties showed significant responses to thermal modification after the most intensive treatment level had been applied. Despite the degradation of mechanical properties in both species, an optimal combination of temperature and treatment time could be achieved. The recorded changes of the tested wood properties in both species could increase the range of applications; the new colour resembled that of highly sought-after tropical hardwoods.
\end{abstract}

\section{Introduction}

The wood consumption associated with the rapidly growing human population is outpacing the capacity of natural forests to meet the demand. This is particularly the case in the tropics, where, in spite of a high diversity of wood species, only few are selectively harvested, albeit at unprecedented alarming rates (Uetimane et al. 2018). Numerous tropical

Veikko Möttönen

veikko.mottonen@luke.fi

1 Faculty of Agronomy and Forest Engineering, 257 Maputo, Mozambique

2 Agrarian National Research Institute, Ministry of Agriculture, 3658 Maputo, Mozambique

3 Natural Resources Institute Finland, Production systems, 80100 Joensuu, Finland hardwood species are overlooked due to poor knowledge of their timber properties, including the local lack of costeffective technologies to process the timber into competitive end products. This is particularly true for the group of light-coloured and perishable timbers where toxic chemicals must be impregnated to ensure their prolonged service life.

Environmental concerns on toxic chemicals impregnated in wood to enhance its properties have triggered research on alternative and environmentally friendly wood-processing methods such as thermal modification. This approach consists of exposing pre-kiln dried wood to high temperatures $\left(180-250{ }^{\circ} \mathrm{C}\right)$ for relatively short periods, resulting in changes in its natural structure. Typically, during thermal modification, permanent changes in wood colour, physicomechanical properties, and chemical composition occur. In general, after thermal treatment, light-coloured wood species tend to acquire darker tones resembling some naturally dark-coloured endangered and precious tropical hardwoods. 
According to Esteves and Pereira (2009), these changes are explained by the increase in phenolic groups and lignin stabilisation during thermal modification. Another typically acquired feature is improved resistance to biodegradation, somewhat associated with acquired hydrophobicity compared to untreated solid wood (Hill 2006; Dubey 2010; Srinivas and Pandey 2012; Militz and Altgen 2014).

The degree of change in wood properties depends on the wood species and the process conditions applied. In general, temperature level along with the duration of the treatment, wood moisture content and oxygen level are the most critical process factors (Bekhta and Niemz 2003; Esteves and Pereira 2009; Gunduz et al. 2009). Typically, there is only a small change in the modulus of elasticity (MOE), but a major decrease in the modulus of rupture (MOR) regardless of the process or species. Several studies have shown that the MOR and the MOE of wood change when it is thermally modified, depending on the temperature and the duration; i.e., the higher the temperature during the treatment, the higher the loss in strength (Militz 2002; International ThermoWood Association 2003; Dagbro 2016).

One of the most important reasons for thermal modification is to obtain a more dimensionally stable material by reducing the equilibrium moisture content (EMC). The reduction in EMC is about 0-50\%, depending on how the treatment is performed (International ThermoWood Association 2003; Militz 2008). Even relatively low thermal treatments result in lower EMC values, with the effect being greater with increasing temperatures (Popper et al. 2005). Esteves et al. (2007) reported a decrease in EMC and dimensional stability due to carbohydrate degradation of pine (Pinus pinaster) and eucalyptus (Eucalyptus globulus) wood, which occurred at low treatment intensities. Unlike untreated solid wood, in general, thermally modified wood does not feature drying stress. This is a clear advantage seen when, for example, splitting the material and manufacturing carpentry products. In addition, wood swelling and shrinkage are low (Sandberg and Kutnar 2016).

Mass loss of wood is one of the most important features in thermal modification and commonly referred to as an indication of quality (Sandberg and Kutnar 2016). Thermal modification at lower temperatures results in low mass loss, mainly associated with loss of volatiles and bound water. Loss of macromolecular components can occur at temperatures above $100{ }^{\circ} \mathrm{C}$ and is of greater significance as time and temperature are increased (Millett and Gerhards 1972).

In Mozambique, thermal wood modification could be a suitable technology for processing non-durable lesser known and lesser used species such as Brachystegia spiciformis (msasa) and Julbernadia globiflora (red msasa). If successfully applied, this technology could potentially open new market opportunities as well as preserve overexploited wood species (Sosef et al. 1998; Peres 2010).
Despite enjoying a large share of the Mozambique forests' growing stocks (Marzoli 2007), both B. spiciformis and $J$. globifora timbers are interchangeably mainly used for railway sleepers after pressure impregnation in creosote treatment plants. This decay-resistive but toxic processing option restricts a wider range of uses. Therefore, in this study, the responses of wood properties induced by different thermal treatment intensities of both B. spiciformis and J. globiflora was assessed. It is expected that an environmentally friendly processing technology such as thermal modification will ensure improved properties of a group of lesser-used species, which could enable their use for both indoor and outdoor applications and relieve pressure on the most sought-after timbers across the country.

\section{Materials and methods}

\subsection{Material and sample origin}

Samples of Brachystegia spiciformis and Julbernadia globiflora were obtained from 10 mature undated dominant trees (five of each species) growing in humid miombo natural forests of Cheringoma District, Sofala Province, Mozambique (S 18 $45^{\prime} 21.9^{\prime \prime}$ E $034^{\circ} 55^{\prime} 27.1^{\prime \prime}$ ). Tree species were confirmed at the Eduardo Mondlane University xylarium through vouchered reference specimens. A batch containing 121 pre-dried boards of B. spiciformis and 64 boards of J. globiflora was transported to Luxhammar Ltd. (Mikkeli, Finland), where the thermal modification treatments were carried out. For the experiment, pre-kiln dried sapwood boards-nominal size $(600 \times 50 \times 25 \mathrm{~mm}$; long $\times$ radial $\times$ tang) of both species (average moisture content $12 \%$ ) —were exposed to three thermal treatment levels and distributed in the sub-sets as shown in Table 1 . All boards were shortened to the length of $500 \mathrm{~mm}$ to fit a laboratory-size $\left(0.5 \mathrm{~m}^{3}\right)$ thermal modification chamber.

\subsection{Thermal modification of wood materials}

The wood samples of both species were heat-treated using the Luxhammar thermal modification process developed by

Table 1 Number of wood samples for each tested thermal modification

\begin{tabular}{lllll}
\hline Treatment & $\begin{array}{l}\text { Tempera- } \\
\text { ture, }{ }^{\circ} \mathrm{C}\end{array}$ & Time, h & $\begin{array}{l}\text { Brachystegia } \\
\text { spiciformis }\end{array}$ & $\begin{array}{l}\text { Julber- } \\
\text { nadia } \\
\text { globiflora }\end{array}$ \\
\hline Untreated & - & - & 9 & 7 \\
T1 & 215 & 2 & 43 & 27 \\
T2 & 230 & 2 & 40 & 29 \\
T3 & 245 & 2 & 29 & - \\
\hline
\end{tabular}


Luxhammar Corporation (Luxhammar 2019). This process consists of five different stages: Initial heating (temperature raised to $100{ }^{\circ} \mathrm{C}$ ), preconditioning and drying, the actual thermal modification with high temperatures up to $250{ }^{\circ} \mathrm{C}$, conditioning (restoration of moisture) and cooling. The heat treatment processes were carried out in an airtight stainlesssteel kiln chamber using three temperature range intensities, $215^{\circ} \mathrm{C}(\mathrm{T} 1), 230{ }^{\circ} \mathrm{C}(\mathrm{T} 2)$ and $245^{\circ} \mathrm{C}(\mathrm{T} 3)$, for $2 \mathrm{~h}$ at a saturated steam environment, one treatment at each temperature. Due to the shortage of wood material of J. globiflora, it was not subjected to treatment T3. However, T3 was used for $B$. spiciformis to enable further studies on the effects of different thermal wood modification processes on resistance to decay and termites.

\subsection{Measurement of wood properties}

For all subsets of specimens, the wood properties listed in Table 2 were tested before and after each thermal treatment level, using untreated samples as reference control. Statistical differences between untreated samples and each treatment level within each wood species were calculated using Tukey's multiple range test at $p<0.005$. The mechanical tests were performed using the universal material testing machine Zwick Z050 (Germany) according to specific standards listed in Table 2.

Mass loss (ML) of all specimens was calculated by weighing before and after each thermal treatment level and expressed in $\%$. Specimens from each treatment were oven-dried to absolute dry weight and compared to monitor changes in the oven-dry density. Likewise, after each treatment, the specimens were left in standard room climate $\left(20{ }^{\circ} \mathrm{C}, 65 \%\right.$ relative humidity) until equilibrium moisture content (EMC) was achieved. The reflectance spectra of each sample were measured over three 8-mm diameter regions using a Konica Minolta CM-2600d portable spectrophotometer. Spectral data between 360 and $740 \mathrm{~nm}$ visible wavelength range were converted to CIEL*a*b* colour coordinates using $2^{\circ}$ standard observer and D65 light source. Lastly, the colour difference $\left(\Delta E^{*}{ }_{a b}\right)$ between the modified and unmodified specimens was calculated using the CIE76 standard (Commission International de l'Eclairage, CIE), which corresponds to the distance between two points in the three-dimensional colour coordinate system and is calculated by the following equation:

$\Delta E^{*}{ }_{a b}=\left(\left(\Delta L^{*}\right)^{2}+\left(\Delta a^{*}\right)^{2}+\left(\Delta b^{*}\right)^{2}\right)^{1 / 2}$

where $\Delta L^{*}, \Delta a^{*}$ and $\Delta b^{*}$ reflect the changes in lightness $\left(L^{*}\right)$ and the chromatic parameters redness $\left(a^{*}\right)$ and yellowness $\left(b^{*}\right)$ between the measurements on the treated samples. In each specimen, colour was measured on the same marked spot after polishing to avoid reflectance of eventual moisture or resin stains.

Brinell hardness $(H B, \mathrm{MPa})$ of wood was measured from the tangential surface with a size of $25 \times 50 \times 50 \mathrm{~mm}$ and calculated according to EN 1534 (2010) as follows:

$H B=2 F /\left(\pi^{*} D^{*}\left(D-\left(D^{2}-d^{2}\right)^{1 / 2}\right)\right.$,

where $F$ is the nominal force $(\mathrm{N}), D$ is the diameter of the steel ball $(\mathrm{mm})$ and $d$ is the diameter of the residual indentation (mm). As a difference from EN 1534 (2010), the estimated value for the diameter of the residual indentation $(d, \mathrm{~mm})$ was calculated from the depth of the residual indentation $(h, \mathrm{~mm})$ measured by the material testing machine as follows:

$d=2 \times\left(10 h-h^{2}\right)^{1 / 2}$

The tests for modulus of elasticity, $\operatorname{MOE}\left(E_{w}, \mathrm{MPa}\right)$ and modulus of rupture, MOR $\left(\sigma_{b, W}, \mathrm{MPa}\right)$ were carried out according to standards ISO 13061-4 (2014) and ISO 13061-3 (2014), respectively, using $20 \times 20 \times 340 \mathrm{~mm}$ clear wood specimens as follows:

$E_{w}=P l^{3} / 4 b h^{3} f$,

where $P$ is the load equal to the difference between the upper and lower limits of loading $(\mathrm{N}), l$ is the span $(\mathrm{mm})$, $b$ is the width of the test specimen (mm), $h$ is the height of the test specimen $(\mathrm{mm}), f$ is the deflection at the upper and lower limits of loading (mm), and:

$\sigma_{b, W}=3 P_{\max } l / 2 b h^{2}$,

where $P_{\max }$ is the maximum load $(\mathrm{N}), l$ is the span $(\mathrm{mm})$, $b$ is the width of the test specimen (mm) and $h$ is the height of the test specimen $(\mathrm{mm})$. The specimens were prepared so
Table 2 Tested wood properties and specific standards

\begin{tabular}{ll}
\hline Tested wood properties & Standard \\
\hline Equilibrium moisture content, mass loss and oven-dry density & ISO 13061-1:2014 \& ISO 13061-2:2014 \\
Colour/spectral reflectance & ISO/CIE 11664-6:2014 \\
Bending strength: MOE \& MOR* & ISO 13061-3:2014 \& ISO 13061-4:2014 \\
Brinell hardness & EN 1534:2010 \\
Compression strength & ISO 13061-17:2017 \\
\hline
\end{tabular}

MOE Modulus of elasticity, MOR modulus of rupture, ISO International Standards Organization 
that one of the faces was as parallel as possible to the direction of the growth ring. The load was applied to the radial surface at the mid-span of the specimens.

The maximum compression strength $\left(\partial_{c, 0, W}, \mathrm{MPa}\right)$ parallel to the grain was determined using clear wood specimens with a size of $20 \times 20 \times 60 \mathrm{~mm}$. The values obtained were used to calculate the compressive strength using the equation below, according to ISO 13061-17 (2017):

$\partial_{c, 0, W}=P_{\max } / a b$,

where $P_{\text {max }}$ is the load in $(\mathrm{N})$, and $a$ and $b$ are the crosssectional dimensions of the specimen $(\mathrm{mm})$.

The figures describing the tested mechanical properties of MOE and MOR (before and after thermal treatments) were adjusted to $12 \%$ moisture content to address moisture variation amongst the subset of specimens modified in different thermal intensities; the following equations were used, which are valid for moisture contents of $12 \pm 5 \%$ :

$E_{12}=E_{w} /(1-\alpha \times(W-12))$

$\sigma_{b, 12}=\sigma_{b, W}[1+\alpha(W-12)]$

where $\alpha$ is the correction factor for the moisture content, equal to 0.04 , and $W$ is the moisture content of wood.

\section{Results and discussion}

\subsection{Colour change}

Thermally modified wood is widely known for its permanent structural changes (e.g., Esteves and Pereira 2009). Colour change in different shades of darkness is probably the most striking and recognised feature of thermally modified wood. Predictably, in this study, all thermal treatment levels produced visible changes in colour as shown by the overall colour change parameter $\left(\Delta E^{*}{ }_{a b}\right)$ and the lightness ( $L^{*}$ ) (Table 3 ); an $\Delta E^{*}{ }_{a b}$ larger than 2 is visually perceived by the naked human eye (Witzel et al. 1973; Hon and Minemura 2001).

Additionally, remarkable uniformity in colour was achieved within each wood sample at all treatment levels for the two species (Fig. 1). The acquired colours could potentially add value to both wood species due to similarities to expensive, rare, endangered precious tropical hardwoods (De Moura et al. 2014). More specifically, the most pronounced colour change was observed with lightness coordinate $L^{*}$. This parameter $\left(L^{*}\right)$ gradually decreased with increasing temperatures; B. spiciformis wood was the brightest, while the wood of J. globiflora was comparatively darker (Fig. 2). The thermally modified samples of all two wood
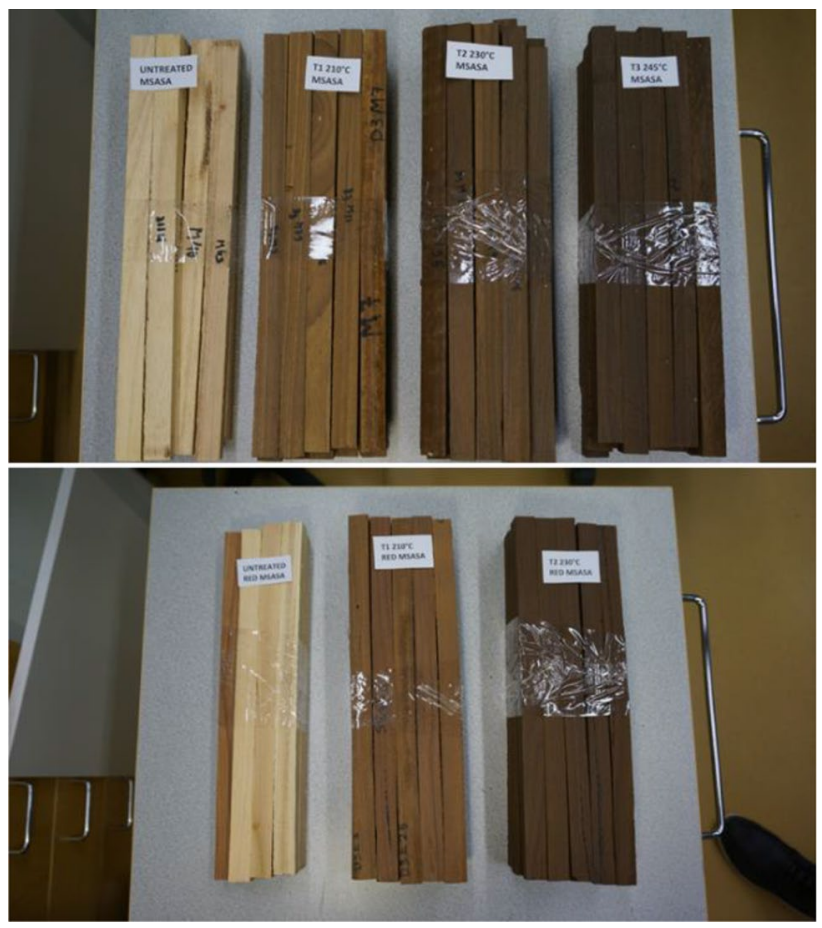

Fig. 1 Bending test specimens of B. spiciformis (above) and $J$. globiflora (below) showing the gradual change of colour, from left: untreated, T1, T2, and T3
Table 3 Colour changes by treatment level and wood species

\begin{tabular}{|c|c|c|c|c|c|}
\hline \multirow[t]{2}{*}{ Wood species } & \multirow[t]{2}{*}{ Treatment } & \multicolumn{3}{|c|}{ Colour coordinate } & \multirow{2}{*}{$\begin{array}{l}\text { Overall colour change } \\
\Delta E^{*}{ }_{a b}\end{array}$} \\
\hline & & $L^{*}$ & $a^{*}$ & $b^{*}$ & \\
\hline \multirow[t]{4}{*}{ B. spiciformis } & Untreated & $77.09(3.73)$ & $6.20(1.90)$ & $23.32(2.11)$ & - \\
\hline & $\mathrm{T} 1$ & $44.54(2.11)$ & $8.98(0.55)$ & $19.75(1.58)$ & $33.33(5.43)$ \\
\hline & $\mathrm{T} 2$ & $36.11(1.49)$ & $7.26(0.56)$ & $13.19(1.58)$ & $42.37(4.17)$ \\
\hline & $\mathrm{T} 3$ & $33.26(1.37)$ & $6.22(0.58)$ & $10.90(1.26)$ & $45.19(7.00)$ \\
\hline \multirow[t]{3}{*}{ J. globiflora } & Untreated & $75.35(6.88)$ & $6.59(2.34)$ & 23.41 (1.97) & - \\
\hline & $\mathrm{T} 1$ & $42.12(2.19)$ & $10.40(0.81)$ & $18.13(1.76)$ & $34.49(3.72)$ \\
\hline & $\mathrm{T} 2$ & $34.00(0.87)$ & $7.44(0.56)$ & $11.28(1.09)$ & $42.87(5.50)$ \\
\hline
\end{tabular}

Standard deviations in parentheses 


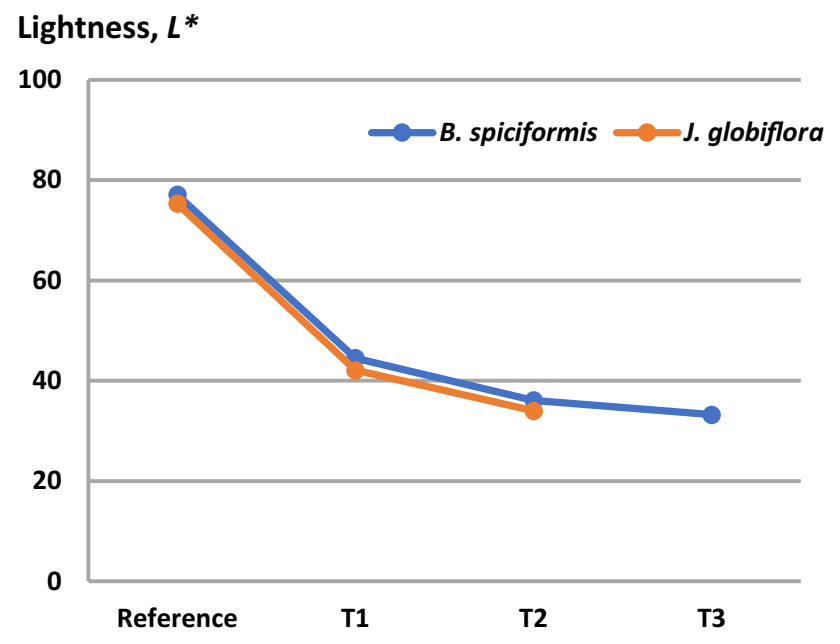

Fig. 2 Change of lightness ( $\left.L^{*}\right)$ between reference (untreated) and thermally modified samples T1-T3

species achieved significant darkness in comparison with the untreated wood samples. For both wood species, these values decreased by more than half after thermal treatment $\mathrm{T} 1$.

Values of coordinate $a^{*}$ increased initially, in treatment $\mathrm{T} 1$ (Table 3), and later decreased with longer exposure (in treatments $\mathrm{T} 2$ and $\mathrm{T} 3$ ). This colour change trend was also previously reported by González-Pena and Hale (2009) and Gurleyen et al. (2018). The decrease in values of $b^{*}$ coordinate means that thermally modified wood had a less saturated colour compared to untreated wood. All these changes in colour could potentially add value to both wood species (De Moura et al. 2014). Colour is a highly important attribute for the final consumer choice. As the decorative look often prevails, colour is a determining factor for the selection of a specific wood (Esteves and Pereira 2009).

\subsection{Mass loss, oven-dry density and equilibrium moisture content}

Mass loss (ML) increased and the equilibrium moisture content (EMC) and oven-dry density decreased as the thermal treatment level was increased (Table 4). The ML of the thermally modified wood is also triggered by the degradation of wood polymers (cellulose, hemicelluloses and lignin), mainly the hemicelluloses, in this range of temperature, which are the most thermally sensitive wood components (Poncsak et al. 2006; Mohebby and Sanaei 2005; Kocaefe et al. 2007). One of the key structural changes in thermally modified wood is improved hydrophobicity and lower ovendry density due to progressive evaporation of extractives and thermal degradation of the main chemical components of wood (Pockrandt et al. 2018). According to Tuong and $\mathrm{Li}$ (2010), an ML between 8.5 and $12 \%$ is sufficient to obtain the maximum reduction in swelling with acacia wood. This
Table 4 Mass loss, EMC and oven-dry density changes after thermal modifications

\begin{tabular}{lllll}
\hline Wood species & $\begin{array}{l}\text { Thermal } \\
\text { treatment } \\
\text { levels }\end{array}$ & ML (\%) & EMC (\%) & $\begin{array}{l}\text { Oven-dry } \\
\text { density }(\mathrm{g} / \\
\left.\mathrm{cm}^{3}\right)\end{array}$ \\
\hline B. spiciformis & Reference & - & $7(0.01) \mathrm{a}$ & $0.65(0.03) \mathrm{a}$ \\
& $\mathrm{T} 1$ & $15(0.01)$ & $4(0.00) \mathrm{b}$ & $0.61(0.07) \mathrm{a}$ \\
& $\mathrm{T} 2$ & $24(0.05)$ & $3(0.00) \mathrm{b}$ & $0.58(0.04) \mathrm{b}$ \\
& $\mathrm{T} 3$ & $27(0.01)$ & $3(0.01) \mathrm{b}$ & $0.55(0.03) \mathrm{b}$ \\
J. globiflora & Reference & - & $8(0.02) \mathrm{a}$ & $0.81(0.10) \mathrm{a}$ \\
& $\mathrm{T} 1$ & $21(0.02)$ & $5(0.02) \mathrm{b}$ & $0.74(0.07) \mathrm{a}$ \\
& $\mathrm{T} 2$ & $24(0.01)$ & $3(0.00) \mathrm{c}$ & $0.74(0.04) \mathrm{b}$ \\
\hline
\end{tabular}

Standard deviation in parentheses; $M L$ mass loss, $E M C$ equilibrium moisture content; Same letters in each group indicate that there is no statistical difference between the samples for each species, according to Tukey's multiple range test at $\mathrm{p}<0.005$

means that the maximum reduction in swelling could already be achieved with $\mathrm{T} 1$ treatment of J. globiflora and B. spiciformis wood.

The reduced EMC of thermally modified wood can be explained by several factors, including the degradation of the amorphous regions of cellulose, triggering cross-linking reactions that potentially hinder moisture intake (Jermer et al. 2003; Mitani and Barboutis 2014; Adeyemi et al. 2017). Hydrophobicity and reduced density are improved wood features with potential for new applications where decay resistance and dimensional stability are critical.

\subsection{Bending strength and stiffness}

Thermal modification induces permanent changes in the wood structure. The wood responses of B. spiciformis and $J$. globifora to thermal modification are shown below (Fig. 3). There was a clear trend of decline in bending strength (MOE) and stiffness (MOR) for both species with increasing treatment intensity; similar trends have been reported elsewhere for hardwoods (Korkut et al. 2008; Korkut 2012).

The MOR of both wood species decreased by over $50 \%$ of the reference value, while the MOE dropped by $10 \%$ in $B$. spiciformis and beyond 6\% in J. globiflora with the highest treatment intensity. According to Tukey's multiple range test (at $\mathrm{p}<0.05$ ), all induced changes are significantly different from the reference untreated samples since thermally modified samples turned brittle. As a result of thermal modification, the modulus of elasticity and the compression strength parallel to the grain of the wood usually decrease less than the bending strength or may even increase even if the brittleness increases (e.g., Boonstra et al. 2007; Heräjärvi 2009; Lekounougou et al. 2011). Both static and dynamic bending 

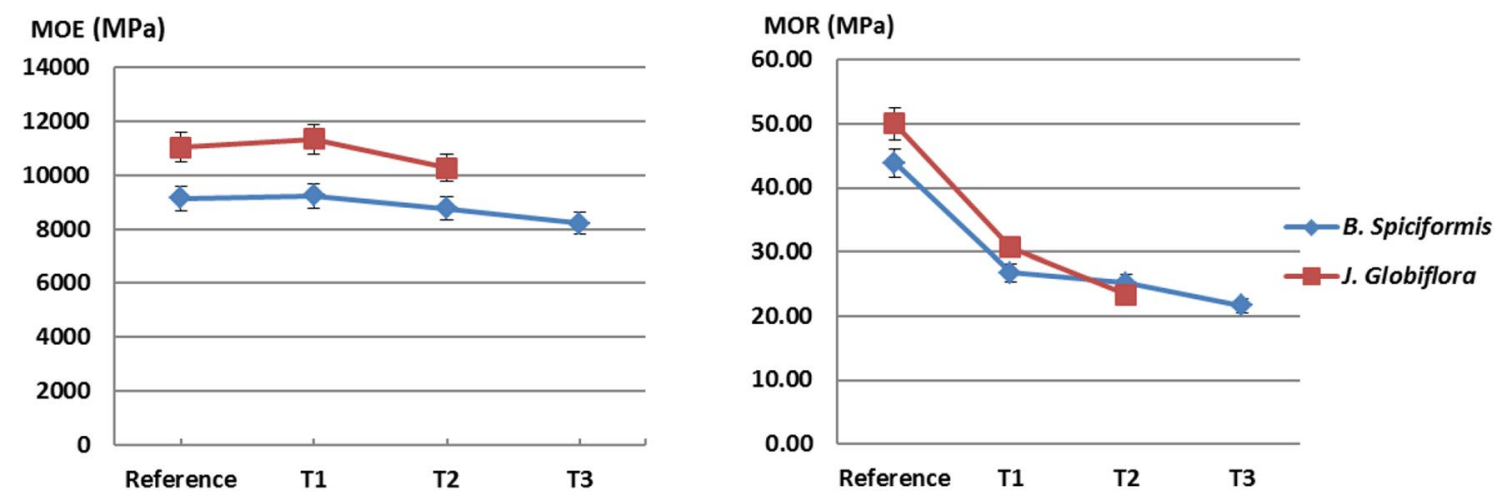

Fig. 3 Bending stiffness and strength changes in timbers of B. spiciformis and J. globiflora after different thermal treatment levels

strength can be reduced by up to 50\% (Esteves and Pereira 2009; Sandberg and Kutnar 2016).

Due to deterioration in mechanical properties, the use of thermally modified wood as load-bearing structural material should be restricted (Jämsa and Viitaniemi 2001; Widmann et al. 2012). However, a balance is needed to establish optimal treatment to allow a wide range of applications for the end-product. For example, treatment T2 seems suitable as no considerable gain was obtained by the intense treatment T3 when applied to B. spiciformis timber.

\subsection{Brinell hardness and compression strength parallel to grain}

As in static bending (MOE and MOR), both compression strength and Brinell hardness suffered statistically significant declines as the thermal treatment intensity was increased (Fig. 4). All treatment levels caused decreases in Brinell hardness for B. spiciformis. Exceptionally, a slight increase was recorded for the $J$. globiflora sample subjected to T1, but a decrease for the same sample subjected to T2. Brinell hardness is an important quality parameter for parquet and flooring materials as it measures the resistance against indentation. The resulting values of Brinell hardness after T1 treatment for B. spiciformis (26.0 MPa) and T2 treatment for J. globiflora (32.4 MPa) are within the range of most wood floorings. However, the Brinell hardness of B. spiciformis samples subjected to T3 (20.2 MPa) was not comparable to that of untreated birch (23.4 MPa) or oak (30.5 MPa) wood (Heräjärvi 2004; Swaczyna et al. 2011), which typically are used as flooring materials in Europe. In thermal modification, the brittleness of the wood also increases, i.e. the ability of elastic deformation decreases (e.g., Lekounougou et al. 2011; Widmann et al. 2012), which, however, does not necessarily mean a decrease in stiffness or strength. This is observed, for example, in the Brinell hardness test of the surface, where the measurement trace caused to heattreated wood does not recover over time like the trace made on untreated wood (Heräjärvi et al. 2006).

For both species, thermal treatment led to a $20 \%$ decrease in compression strength parallel to the grain. Similar results were claimed by Korkut (2012), who studied wood responses of three thermally treated tropical hardwood species. As mentioned earlier, mild thermal intensity treatment should be
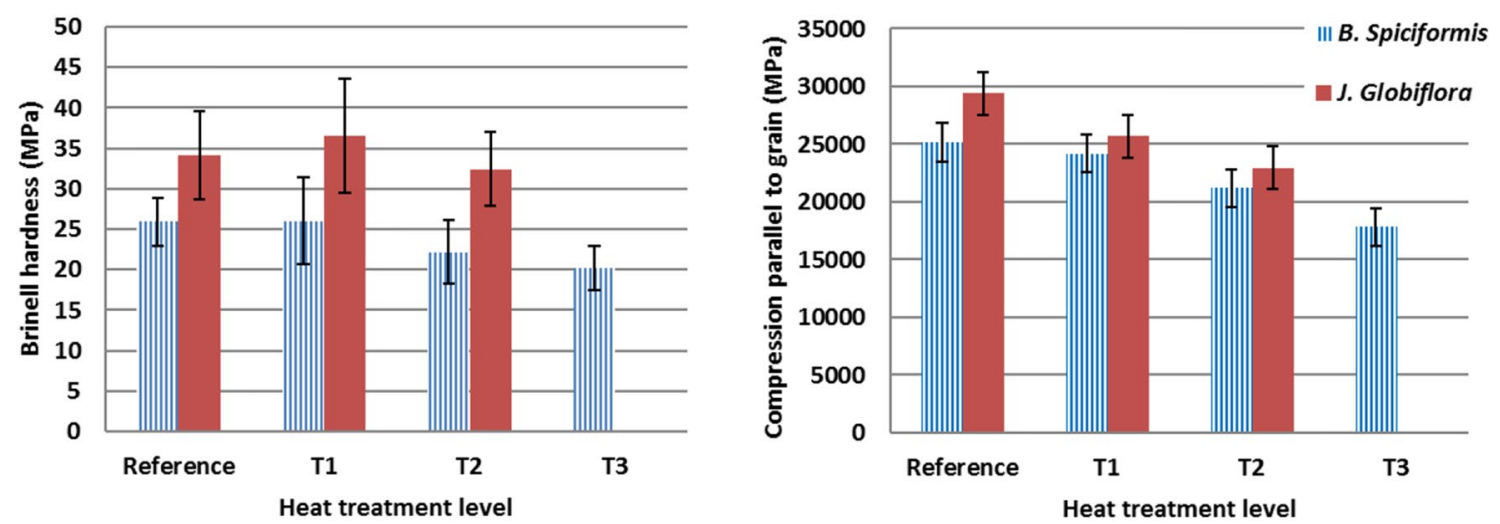

Fig. 4 Changes in Brinell hardness and compression strength of B. spiciformis and J. globiflora after thermal modification 
deployed if the decrease in strength properties is to be kept within critical limits.

\section{Conclusion}

The responses of wood properties to thermal treatment were tested for two low-value and abundant, but relatively lesser known/used native hardwoods from Mozambique. Based on the measured parameters, it can be concluded that nearly all measured wood properties experienced statistically significant changes after all treatment levels. More specifically, from control reference samples to the highest treatment level, the results show that $B$. spiciformis timber experienced a maximum mass loss of $27 \%$, while the oven-dry density was reduced from 0.65 to $0.56 \mathrm{~g} / \mathrm{cm}^{3}$ and the EMC dropped from 7 to $3 \%$. With regard to J. globiflora, the ML induced by the highest treatment level was $23 \%$, oven-dry density decreased from 0.81 to $0.74 \mathrm{~g} / \mathrm{cm}^{3}$ and the EMC was reduced from 8 to $3 \%$. Changes in mechanical properties were also significant from reference samples to the highest treatment. For B. spiciformis, MOE reduced from 9150 to $8212 \mathrm{MPa}$ (10.2\%), MOR from 43.88 to $21.60 \mathrm{MPa}$ (50.8\%), compression strength parallel to the grain decreased from 25129 to $17794 \mathrm{MPa}(29.2 \%)$ and Brinell hardness from 2.64 to $2.02 \mathrm{MPa}(23.5 \%)$. The samples from $J$. globiflora followed the same trend, with $\mathrm{MOE}$ reducing from 11037 to $10277 \mathrm{MPa}$ (6.9\%), MOR from 50.02 to $23.39 \mathrm{MPa}$ (53.2\%) and compression strength parallel to the grain from 29365 to $22935 \mathrm{MPa}(21.9 \%)$.

It is, therefore concluded that thermally modified wood of both species could potentially be used for flooring due to the new darker colour and the low EMC associated with hydrophobicity. Overall, the current results suggest that thermal modification is potentially an effective method for processing low-value, but abundant wood species to relieve the current pool of overexploited tropical hardwoods.

Acknowledgements Open access funding provided by Natural Resources Institute Finland (LUKE). The study was carried out in the framework of a project (FORECAS II project) financed by the Ministry for Foreign Affairs of Finland, to which financial support is gratefully acknowledged. The authors also gratefully acknowledge LevasFlor Ltd. (Beira, Mozambique) for providing the sawn wood material for the tests and Luxhammar Ltd. (Mikkeli, Finland) for carrying out the thermal modification treatments.

\section{Compliance with ethical standards}

Conflict of interest On behalf of all authors, the corresponding author states that there is no conflict of interest.

Open Access This article is licensed under a Creative Commons Attribution 4.0 International License, which permits use, sharing, adaptation, distribution and reproduction in any medium or format, as long as you give appropriate credit to the original author(s) and the source, provide a link to the Creative Commons licence, and indicate if changes were made. The images or other third party material in this article are included in the article's Creative Commons licence, unless indicated otherwise in a credit line to the material. If material is not included in the article's Creative Commons licence and your intended use is not permitted by statutory regulation or exceeds the permitted use, you will need to obtain permission directly from the copyright holder. To view a copy of this licence, visit http://creativecommons.org/licenses/by/4.0/.

\section{References}

Adeyemi IE, Babatola O, Mayowa OJ, Adeola FJ (2017) Impact of heat treatment on physico-mechanical properties of thermally modified Anthocleistha djalonensis wood. JMSA 3(2):28-34

Bekhta P, Niemz P (2003) Effect of high temperature on the change in color, dimensional stability and mechanical properties of spruce wood. Holzforschung 57(5):539-546

Boonstra MJ, Van Acker J, Kegel E (2007) Effect of a two-stage heat treatment process on the mechanical properties of full construction timber. Wood Mater Sci Eng 3-4:138-146

Dagbro O (2016) Studies on industrial-scale thermal modification of wood. doctoral thesis. Department of Engineering Sciences and Mathematics, Luleå University of Technology. Retrieved from https://www.diva-portal.org/smash/get/diva2:999791/FULLT EXT01.pdf

De Moura LF, Dos Santos DVB, Brito JO (2014) Effect of heat treatment on color, weight loss, specific gravity and equilibrium moisture content of two low market valued tropical woods. Wood ResSlovakia 59(2):253-264

Dubey MK (2010) Improvements in stability, durability and mechanical properties of radiata pine wood after heat-treatment in a vegetable oil. PhD Thesis. University of Canterbury, New Zeland. 211 pp

EN 1534 (2010) Wood flooring. Determination of resistance to indentation. Test method, Brussels

Esteves BM, Pereira HM (2009) Wood modification by heat treatment: a review. Bioresources 4(1):370-404

Esteves B, Marques AV, Domingos I, Pereira H (2007) Influence of steam heating on the properties of pine (Pinus pinaster) and eucalypt (Eucalyptus globulus) wood. Wood Sci Technol 41(3): 193-207

González-Pena MM, Hale MDC (2009) Colour in thermally modified wood of beech, Norway spruce and Scots pine. Part 1: Colour evolution and colour changes. Holzforschung 63:385-393

Gunduz G, Aydemir D, Karakas G (2009) The effects of thermal treatment on the mechanical properties of wild Pear (Pyrus elaeagnifolia Pall.) wood and changes in physical properties. Mater Design 30(10):4391-4395

Gurleyen L, Esteves B, Ayata U, Gurleyen T, Cinar H (2018) The effects of heat treatment on colour and glossiness of some commercial woods in Turkey. Drewno 61(201):81-90

Heräjärvi H (2004) Variation of basic density and Brinell hardness within mature Finnish Betula pendula and B. pubescens stems. Wood Fiber Sci 36:216-227

Heräjärvi H (2009) Effect of drying technology on aspen wood properties. Silva Fenn 43(3):433-445

Heräjärvi H, Junkkonen R, Koivunen H, Metros J, Piira T, Verkasalo E (2006) Metsä- ja hybri-dihaapa sahatavaran ja jatkojalosteiden raaka-aineena.(European aspen and hybrid aspen as raw materials for sawing and further processing). Metlan työraportteja / Working Papers of the Finnish Forest Research Institute Metlan työraportteja 31:102

Hill CAS (2006) Wood modification: thermal and other process. John Wiley \& Sons, New York, p 249

Hon DNS, Minemura N (2001) Color and discoloration. In: Hon DNS, Shiraishi N (eds) Wood and cellulosic chemistry. Marcel Dekker, New York, pp 385-442 
International Thermowood Association (2003) ThermoWood ${ }^{\circledR}$ Handbook. Retrieved from http://www.vanhoorebeke.com/docs/Therm owoodhandboek.pdf

ISO 13061-1 (2014) Physical and mechanical properties of wood-Test methods for small clear wood specimens-Part 1: Determination of moisture content for physical and mechanical tests. International Standards Organisation, Geneva

ISO 13061-2 (2014) Wood-Determination of density for physical and mechanical tests. International Standards Organisation, Geneva

ISO 13061-3 (2014) Physical and mechanical properties of wood-Test methods for small clear wood specimens-Part 3: Determination of ultimate strength in static bending. International Standards Organisation, Geneva

ISO 13061-4 (2014) Physical and mechanical properties of wood-Test methods for small clear wood specimens-Part 4: Determination of modulus of elasticity in static bending. International Standards Organisation, Geneva

ISO 13061-17 (2017) Physical and mechanical properties of woodTest methods for small clear wood specimens-Part 17: Determination of ultimate stress in compression parallel to grain. International Standards Organisation, Geneva

ISO/CIE 11664-6 (2014) Colorimetry - Part 6: CIEDE2000 Colour difference formula. International Standards Organisation, Geneva

Jämsä S, Viitaniemi P (2001) Heat treatment of wood- Better durability without chemicals. In: Proceedings of special seminar held in Antibes, France, $68 \mathrm{p}$

Jermer J, Bengtsson C, Brem F, Clang A, Ek-Olausson B, Edlund M (2003) Heat-treated wood-durability and technical properties Swedish Wood Association project 2001-025

Kocaefe D, Chaudhry B, Poncsak S, Bouazara M, Pichette A (2007) Thermogravimetric study of high temperature treatment of aspen: effect of treatment parameters on weight loss and mechanical properties. J Mater Sci 42(3):355-361

Korkut S (2012) Performance of three thermally treated tropical wood species commonly used in Turkey. Ind Crop Prod 36(1):355-362

Korkut S, Akgül M, Dündar T (2008) The effects of heat treatment on some technological properties of Scots pine (Pinus sylvestris L.) wood. Bioresource Technol 99(6):1861-1868

Lekounougou S, Kokaefe D, Oumarou N, Kokaefe Y, Poncsak S (2011) Effect of thermal modification on mechanical properties of Canadian white birch (Betula papyrifera). Int Wood Prod J 2(2):101-107

Luxhammar (2019) Luxhammar thermal modification technology. Available at: http://www.luxhammar.com/index.php

Marzolli A (2007) Inventário Florestal Nacional: Avaliação integrada das florestas de Moçambique. (National Forest Inventory: Integrated assessment of forests of Mozambique). Direcção Nacional de Terra e Florestas, Ministério da Agricultura. Maputo. 92 pp

Militz H (2002) Heat treatment technologies in Europe: Scientific background and technological state-of-art. Conference on "Enhancing the Durability of Lumber and Engineered Wood Products," (November 2000), 1-19

Militz H (2008) Processes and properties of thermally modified wood manufactured in Europe. In: Schultz TP, Militz H, Freeman MH, Goodell B, Nicholas DD (eds) Development of Commercial Wood Preservatives. ACS Symposium Series, Vol. 982, Chap. 22, pp 372-388
Militz H, Altgen M (2014) Processes and Properties of Thermally Modified Wood Manufactured in Europe. In: Schultz TP, Goodell P, Nicholas DD (eds) Deterioration and Protection of Sustainable Biomaterials. ACS Symposium Series, Vol. 1158, Chap. 16, pp 269-285

Millett MA, Gerhards CC (1972) Accelerated aging: residual weight and flexural properties of wood heated in air at $115^{\circ}$ to $175^{\circ} \mathrm{C}$. Wood Sci 4(4):193-201

Mitani A, Barboutis I (2014) Changes caused by heat treatment in color and dimensional stability of beech (Fagus sylvatica L.) Wood. Drvna Ind 65(3):225-232

Mohebby B, Sanaei I (2005) Influences of the hydro-thermal treatment on physical properties of beech wood (Fagus orientalis). In: Annual Meeting Bangalore (36), Proceedings. Tarbiat Modarress University, New Delhi

Peres CA (2010) Overharvesting. In: Sodhi NS, Ehrlich PR (eds) Conservation biology for all. Oxford Biology, Oxford, pp 107-130

Pockrandt M, Jebrane M, Cuccui I, Allegretti O, Uetimane E Jr, Terziev N (2018) Industrial Thermowood ${ }^{\circledR}$ and Termovuoto thermal modification of two hardwoods from Mozambique. Holzforschung 72(8):701-709

Poncsak S, Kocaefe D, Bouazara M, Pichette A (2006) Effect of high temperature treatment on the mechanical properties of birch (Betula papyrifera). Wood Sci Technol 40(8):647-663

Popper R, Niemz P, Eberle G (2005) Untersuchungen zum Sorptionsund Quellungsverhalten von thermisch behandeltem Holz. (Investigations on the sorption and swelling properties of thermally treated wood). Holz Roh Werkst 63:135-148

Sandberg D, Kutnar A (2016) Thermally modified timber: recent developments in Europe and North America. Wood Fiber Sci 48:28-39

Sosef MSM, Hong LT, Prawirohatmodjo S (1998) Plant Resources of South-East Asia No 5(3) Timber Trees: Lesser- Known timbers. Backhuys Publishers. 859 pp

Srinivas K, Pandey KK (2012) Effect of heat treatment on color changes, dimensional stability, and mechanical properties of wood. J Wood Chem Tech 32:304-316

Swaczyna I, Kędzierski A, Tomusiak A, Cichy A, Różańska A (2011) Hardness and wear resistance tests of the wood species most frequently used in flooring panels. Ann WULS-SGGW Forestry and Wood Technology 76:82-87

Tuong VM, Li J (2010) Effect of heat treatment on the change in color. Bioresources 5(2): 1257-1267

Uetimane E Jr, Jebrane M, Terziev N, Daniel G (2018) Comparative wood anatomy and chemical composition of Millettia mossambicensis and Millettia stuhlmannii from Mozambique. Bioresources 13(2):3335-3345

Widmann R, Fernandez-Cabo JL, Steiger R (2012) Mechanical properties of thermally modified beech timber for structural purposes. Eur J Wood Prod 76(6):775-784

Witzel RF, Burnham RW, Onley JW (1973) Threshold and supra threshold perceptual color differences. J Opt Soc Am 63(5):615-625

Publisher's Note Springer Nature remains neutral with regard to jurisdictional claims in published maps and institutional affiliations. 